\title{
Measurements of bacterial production in coastal marine environments using leucine: application of a kinetic approach to correct for isotope dilution
}

\author{
Arthur van Looij ${ }^{1}$, Bo Riemann ${ }^{2}$ \\ 'Wageningen Agricultural University, Department of Nature Conservation, Ritzemabosweg 32A, 6700 DD, Wageningen, \\ The Netherlands \\ ${ }^{2}$ The International Agency for ${ }^{14} \mathrm{C}$ Determination, The Water Quality Institute, Agern Allé 11, DK-2970 Horsholm, Denmark
}

\begin{abstract}
Bacterial carbon production was measured daily by means of leucine and thymidine incorporation in samples from 2 locations in the eutrophic Roskilde Fjord, Denmark. During periods of $2 \mathrm{wk}$ in March, June, and September 1992, rates of leucine incorporation using $50 \mathrm{nM}$ leucine were significantly correlated $(r=0.88, n=77$ ) to thymidine-based production rates. To correct for external isotope dilution, the maximal rate of leucine incorporation $\left(V_{\max }\right)$ was calculated from additions of subsaturating concentrations of ${ }^{14} \mathrm{C}$ leucine (1 to $100 \mathrm{nM}$ ). During September, the average isotope dilution was $2.7(\mathrm{SD}=1.4, \mathrm{n}=25)$ and $2.0(\mathrm{SD}=0.8, \mathrm{n}=25)$ times higher than rates obtained from additions of 50 or $100 \mathrm{nM}$ leucine, respectively. The correlation coefficient $\mathrm{r}$ between leucine and thymidine increased from 0.79 to 0.88 when leucine incorporation rates were corrected for isotope dilution. In these eutrophic samples, it is necessary to add more than $200 \mathrm{nM}$ to maximize leucine incorporation and to reduce isotope dilution.
\end{abstract}

KEY WORDS: Bacteria Isotope dilution Leucine - Production

\section{INTRODUCTION}

Bacterial carbon production is a major flux in the biological carbon cycle of aquatic ecosystems. It constitutes 20 to $40 \%$ of the phytoplankton primary production in the water column of freshwater and marine ecosystems (Cole et al. 1988, Ducklow et al. 1993) and is a measure of the richness of the pool of dissolved organic matter (Billen et al. 1988).

Thymidine incorporation into DNA and leucine incorporation into proteins are most often used to determine activity, growth rates, and carbon production of aerobic bacteria (reviews by Riemann \& Bell 1990, Ducklow \& Carlson 1992, see also Riemann et al. 1990, Bjornsen \& Kuparinen 1991). In the hypolimnion and in sediments, however, anaerobic bacteria fail to incorporate external added thymidine into DNA (Winding 1992), probably because they lack thymidine kinase (Moriarty 1986).
Leucine incorporation into bacterial protein can provide a measure of carbon production without the need to know the bacterial cell volumes (Simon \& Azam 1989, Riemann \& Azam 1992), but isotope dilution of added leucine by extracellular and intracellular sources has to be taken into account (Simon \& Azam 1989).

Simon \& Azam (1989) demonstrated that isotope dilution could be overwhelmed by addition of $10 \mathrm{nM}$ leucine in water samples off Scripps Pier (California, USA). In more eutrophic environments, however, unlabelled leucine is found in concentrations ranging from < $1 \mathrm{nM}$ to $>30 \mathrm{nM}$ (Jørgensen 1982, 1987), which makes it difficult to saturate the system by the addition of one single concentration of radio-labelled leucine. If a large concentration $(\mu \mathrm{M})$ of leucine is added, changes in bacterial protein synthesis might occur, or other organisms might incorporate leucine. To correct for isotope dilution in environmental samples with 
fluctuating leucine regimes, Riemann \& Azam (1992) suggested that protein synthesis be measured in subsamples to which a number of subsaturated concentrations of radioactively labelled leucine had been added. On the basis of incorporation kinetics, a non-linear regression of the incorporation velocity of the leucine added was carried out, and the maximal incorporation rate $V_{\max }$ was calculated.

In this study, the kinetic approach, suggested by Riemann \& Azam (1992), was applied to determine the maximal leucine incorporation rate and to evaluate potential isotope dilution in samples from shallow coastal environments. We thought to evaluate shortand long-term coupling between leucine and thymidine by determining day-by-day changes during 3 periods of the growth season.

\section{MATERIALS AND METHODS}

Sampling sites. Water samples were taken daily during 3 to 15 March, 18 June to 1 July and 7 to 20 September 1992 from the eutrophic Roskilde Fjord, Denmark. Water samples were collected from 2 stations located on a transect north of the city Frederikssund (Stns 1 \& 3). Depths of locations varied from 0.5 to about $5 \mathrm{~m}$, and the water samples (taken in duplicate) consisted of water mixed from 2 or 3 depths in the vertical profile. The water samples were brought into the laboratory for analysis of biological activity and chemical constituents. Measurements of biological activity were initiated within $2 \mathrm{~h}$ of sampling.

Bacterial production. Leucine incorporation was carried out according to Simon \& Azam $(1989) .{ }^{14} \mathrm{C}$ leucine $\left(307 \mathrm{mCi} \mathrm{mmol}{ }^{-1}\right.$; New England Nuclear, Boston, MA, USA) was used. Duplicate volumes of $10 \mathrm{ml}$ from each sample were incubated with leucine at the in situ temperature for $1 \mathrm{~h}$. Incubation was terminated using formalin ( $0.8 \%$ final concentration). Two methodological approaches were applied to determine the bacterial carbon production from incorporation of leucine.

The first approach was carried out using water from all 3 periods: ${ }^{14} \mathrm{C}$-leucine incorporation was carried out according to Simon \& Azam (1989), with addition of $50 \mathrm{nM}{ }^{14} \mathrm{C}$-leucine. After incubation, the formalinfixed samples were filtered through Sartorius cellulose-nitrate filters $(0.45 \mu \mathrm{m}$ stated pore size, $25 \mathrm{~mm}$ in diameter), and rinsed with ice-cold 5\% TCA 6 times. The filters were stored in $6 \mathrm{ml}$ plastic vials, and after addition of scintillation cocktail (Ecoscint A, BN Plastic, Espergærde, Denmark), samples were shaken for 10 min, and counted in a scintillation counter (LKB Wallac 1214 Rackbeta) after storage for at least $18 \mathrm{~h}$.
The second approach was carried out using water from the September sampling period. Triplicate volumes of $10 \mathrm{ml}$ were incubated with additions of ${ }^{14} \mathrm{C}$. leucine ranging from 1 to $100 \mathrm{nM}$. Two blanks were made for each leucine concentration.

Incorporation rates of leucine (mol leucine $\mathrm{l}^{-1} \mathrm{~h}^{-1}$ ) were converted to bacterial carbon production according to Simon \& Azam (1989). Unless stated otherwise, bacterial carbon production, $\mathrm{BCP}(\mathrm{g})$, was calculated from the equation:

$$
\mathrm{BCP}=\left(\text { mol leucine }_{\mathrm{inc}}\right) \times 1792 \times 0.86
$$

where (mol leucine ${ }_{\text {inc }}$ ) is mol leucine incorporated into protein, 1792 is computed from the mol\% of leucine in protein $(100 / 7.3) \times 131.2$ (formula weight of leucine) and 0.86 is the carbon content of protein.

On the basis of hyperbolic incorporation kinetics, a calculation of the maximal bacterial carbon production was performed using a non-linear regression (Leatherbarrow 1987).

Measurements of bacterial carbon production from rates of ${ }^{14} \mathrm{C}$-leucine incorporation were compared with results derived from rates of ${ }^{3} \mathrm{H}$-thymidine incorporation. The procedure of Fuhrman \& Azam (1980) was applied using $10 \mathrm{nM}$ thymidine $\left(20 \mu \mathrm{Ci} \mathrm{nmol}^{-1}\right.$ methylthymidine; New England Nuclear). Triplicate samples and 2 blanks were incubated for $30 \mathrm{~min}$ at in situ temperature. Blanks were prepared by adding formaldehyde to a final concentration of $0.8 \%$. When bacterial cell production was calculated, a conversion factor of $1.1 \times 10^{18}$ cells $\mathrm{mol}^{-1}$ thymidine incorporated was applied (Riemann et al. 1987). Bacterial cell volumes were measured from enlarged acridine-orange-dyed (Hobbie et al. 1977), black-and-white photographs exposed to a screen (Lee \& Fuhrman 1987). A total of 100 cells per filter were measured. Biovolumes were converted to carbon biomass by multiplying by $0.35 \mathrm{pg} \mathrm{C} \mu \mathrm{m}^{-3}$ (Bjørnsen 1986).

Ethanol rinsing experiments. The effects of ethanol rinsing (Wicks \& Robarts 1988, Hollibaugh \& Wong 1992) were examined using water samples from 8 coastal stations located around the northern part of the island of Zealand, Denmark. Samples were incubated with ${ }^{14} \mathrm{C}$ leucine at in situ temperature for $1 \mathrm{~h}$. After incubation, the samples were killed using formalin ( $0.8 \%$ final concentration), filtered through Sartorius membrane filters, and rinsed 6 times with ice-cold TCA. Half the filters were subsequently rinsed 3 times with ice-cold $80 \%(\mathrm{v} / \mathrm{v})$ ethanol.

Effects of leucine on thymidine incorporation rate. A series of concentrations of unlabelled leucine $(0,10$, 50 , and $200 \mathrm{nM}$ ) were added to triplicate $50 \mathrm{ml}$ volumes of seawater collected off the coast of the city of Rungsted and from a shallow freshwater pond situated at the Water Quality Institute in Hørsholm. Triplicate 


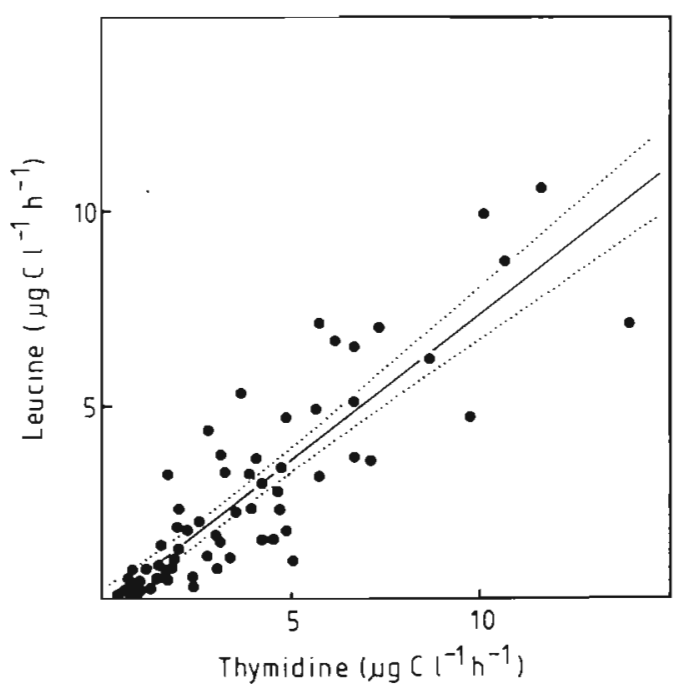

Fig. 1. Bacterial carbon production $\left(\mu \mathrm{g} \mathrm{Cl}^{-1} \mathrm{~h}^{-1}\right)$ measured by means of thymidine incorporation versus leucine incorporation. Data from March, June and September. $95 \%$ confidence limits (CL) are indicated

water samples $(10 \mathrm{ml})$ were incubated at in situ temperature with $10 \mathrm{nM}{ }^{3} \mathrm{H}$-thymidine 0,2 and $6 \mathrm{~h}$ after the addition of leucine, and the results were compared with results from samples without additions of leucine.

\section{RESULTS}

\section{Leucine vs thymidine incorporation rate}

Bacterial carbon production, determined by leucine (50 $\mathrm{nM}$ additions) and thymidine, from March, June, and September covered 2 orders of magnitude and ranged from 0.15 to $14.9 \mu \mathrm{g} \mathrm{Cl}^{-1} \mathrm{~h}^{-1}$. A significant correlation between leucine and thymidine incorporation rates $(\mathrm{r}=0.88, \mathrm{n}=77$ ) was observed (Fig. 1), and the regression equation was: leucine $=0.745$ thymidine 0.095 . The average mole ratio (leucine incorporation/thymidine incorporation) was 28 ( $\mathrm{SD}=12, \mathrm{n}=28$ ).

\section{Concentration-dependent incorporation of leucine}

During September, the kinetic approach was carried out 28 times from 2 stations, and 8 curves were selected to cover the observed variations (Fig. 2). The patterns included hyperbolic saturation curves with different curvatures to almost straight lines. Additions of $100 \mathrm{nM}$ leucine did not saturate the incorporation rate in any experiment. The calculated $V_{\max }$ values varied from 0.64 to $15.95 \mu \mathrm{g} \mathrm{C} \mathrm{l}^{-1} \mathrm{~h}^{-1}$ (Table 1), and the coefficient of variation (SD as percentage of the
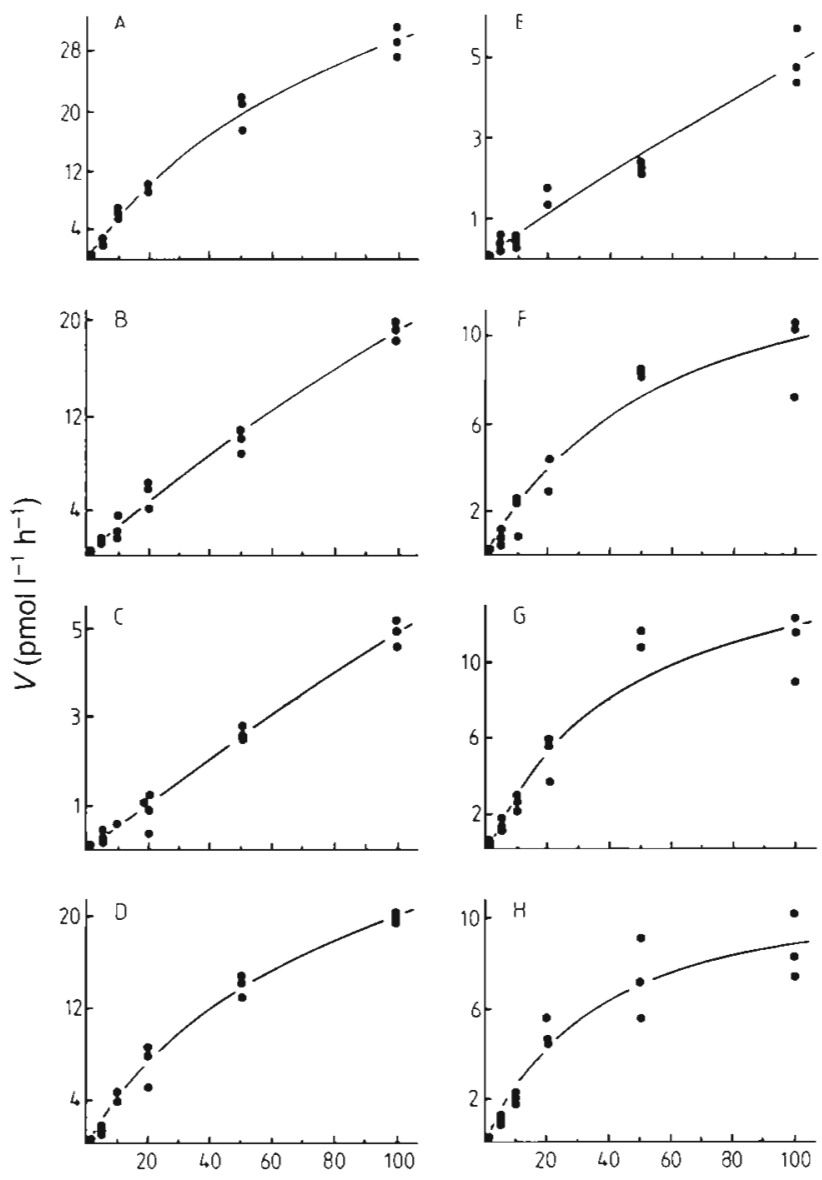

Leucine $(\mathrm{nM})$

Fig. 2. Eight examples of the concentration-dependent incorporation of leucine. (A to D) Results from Stn 1 (shallow).

(E to H) Results from Stn 3

Table 1. Calculated maximal bacterial carbon production $\left(V_{\max } \mu \mathrm{g} \mathrm{C}^{-1} \mathrm{~h}^{-1}\right)$ for $\operatorname{Stn} 1(0.5 \mathrm{~m}$ depth) and $\operatorname{Stn} 3(4.5 \mathrm{~m}$ depth). Standard deviations in parentheses

\begin{tabular}{|c|c|c|}
\hline \multirow{2}{*}{$\begin{array}{l}\text { Date } \\
\text { (Sep 1992) }\end{array}$} & \multicolumn{2}{|c|}{$V_{\max }$} \\
\hline & Stn 1 & Stn 3 \\
\hline 7 & $2.53(0.47)$ & $1.61 \quad(0.59)$ \\
\hline 8 & $2.86(0.76)$ & $5.60(2.26)$ \\
\hline 9 & $5.52(0.47)$ & $1.83(0.25)$ \\
\hline 10 & $3.67(0.86)$ & $2.60(0.32)$ \\
\hline 11 & $6.32(1.51)$ & $2.78(0.27)$ \\
\hline 12 & $9.73(3.47)$ & $2.82(0.43)$ \\
\hline 13 & $9.18(2.76)$ & $2.36(0.38)$ \\
\hline 14 & $4.73(1.31)$ & $2.93(1.00)$ \\
\hline 15 & $15.95(5.35)$ & $3.17 \quad(1.69)$ \\
\hline 16 & $8.95(0.88)$ & $1.59(0.14)$ \\
\hline 17 & $1.70(0.44)$ & $1.15(0.08)$ \\
\hline 18 & $7.72(0.20)$ & $2.74 \quad(0.40)$ \\
\hline 19 & $2.64 \quad(0.46)$ & $0.64(0.11)$ \\
\hline 20 & $11.35(8.23)$ & $6.91(5.04)$ \\
\hline Mean & $6.63(4.08)$ & $2.76(1.67)$ \\
\hline
\end{tabular}




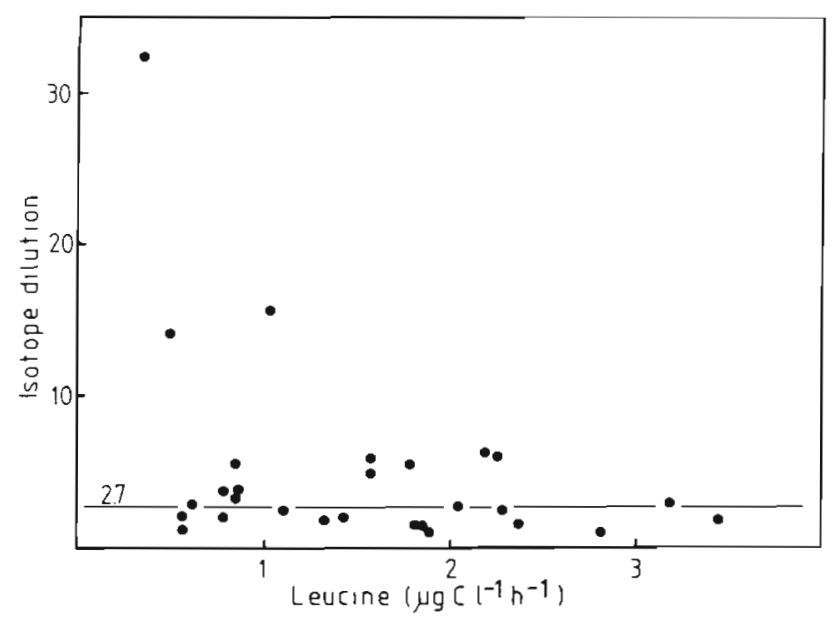

Fig 3. Calculated isotope dilution ( $\left.V_{\max } / 50 \mathrm{nM}\right)$ plotted against the bacterial carbon production measured by means of leucine incorporation ( $50 \mathrm{nM}$ additions)

mean) ranged from 9 to $73 \%$ with a mean value of $25 \%(\mathrm{SD}=17 \%, \mathrm{n}=14)$ for Stn 1 (0.5 m depth), and a mean value of $25 \%(\mathrm{SD}=19 \%, \mathrm{n}=14)$ for Stn 3 (4.5 m depth).

To determine the extracellular isotope dilution when $50 \mathrm{nM}$ additions were used, the ratios between $V_{\max }$ and the incorporation rates measured using $50 \mathrm{nM}$ leucine, assumed to represent the isotope dilution, were calculated (Fig. 3). When 3 outliers were omitted from the data set, the average isotope dilution was 2.7 $(\mathrm{SD}=1.4, \mathrm{n}=25)$. When $100 \mathrm{nM}$ was used, the mean isotope dilution was $2.0(\mathrm{SD}=0.8$, $\mathrm{n}=25$ ). When isotope dilution was

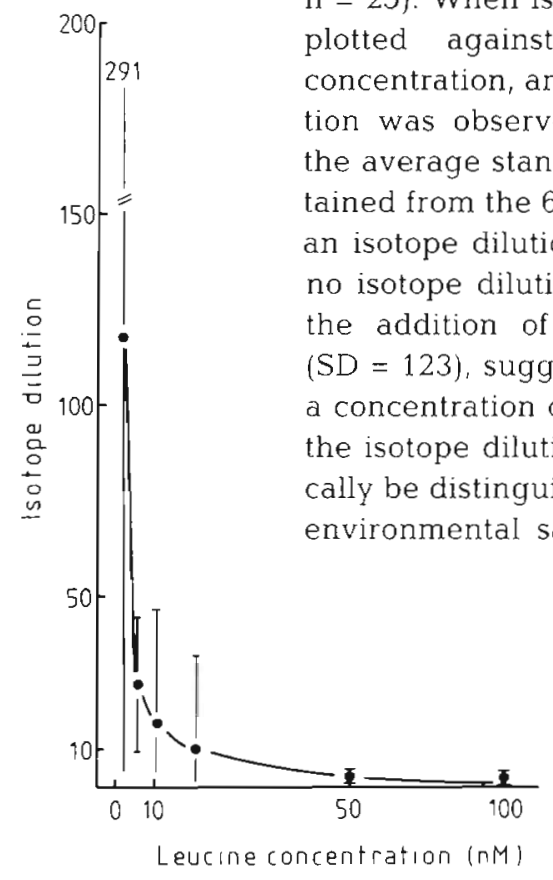

Fig. 4. Calculated isotope dilution plotted against the added leucine concentration

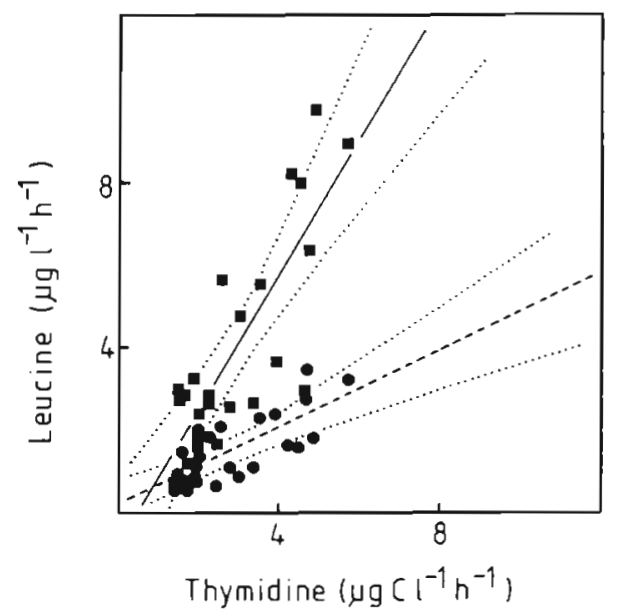

Fig. 5. Bacterial carbon production $\left(\mu \mathrm{g} \mathrm{Cl}^{-1} \mathrm{~h}^{-1}\right)$ measured by means of leucine and thymidine. $(--)$ Without and $(-)$ with correction for isotope dilution. $95 \% \mathrm{CL}$ indicated for each line

\section{Corrections for isotope dilution}

A comparison was made between thymidine incorporation and leucine incorporation without and with corrections for isotope dilution (Fig. 5). For the September data, the correlation between thymidine and leucine without corrections for isotope dilution gave $r=0.79$. The slope was 0.412 , significantly $(p<0.001)$ lower than 1 , and the $y$-intercept was 0.259 . When corrections for isotope dilution were made using the data from Fig. 3, $\mathrm{r}$ increased to 0.88 , and the slope of 1.63 was significantly higher (Student's $t$-test, $\mathrm{p}<0.001$ ) than calculated without correction for isotope dilution.

\section{Effects of rinsing the TCA precipitates with ethanol}

Samples from 8 coastal locations were included to cover the variations in the shallow coastal environments (Table 2). The average ratio between leucine incorporation in samples rinsed without ethanol and in samples with rinsing was 0.97 ( $S D=0.23$ ), suggesting an insignificant ( $p>0.05$ ) difference between unrinsed and rinsed samples.

\section{Eifects of leucine additions on thymidine incorporation}

We sought to determine the influence of leucine additions on the bacterial activity by comparing thymidine incorporation in samples with added leucine $(10$, 50 or $200 \mathrm{nM}$ ), with rates in samples without additions of leucine (Table 3). Thymidine incorporation rates were not significantly higher $(p<0.001$, however, $p<$ 
Table 2. Effect of an alcohol rinsing step on bacterial carbon production (BCP). SD: standard deviation; CV: coefficient of variation. $\mathrm{BCP}_{1}$ : without alcohol rinse; $\mathrm{BCP}_{2}$ : with alcohol rinse

\begin{tabular}{|c|c|c|c|c|c|c|c|}
\hline Location & $\begin{array}{c}\mathrm{BCP}_{1} \\
\left(\mu \mathrm{g} \mathrm{Cl} l^{-1} h^{-1}\right)\end{array}$ & $\mathrm{SD}$ & $\mathrm{CV}$ & $\begin{array}{c}\mathrm{BCP}_{2} \\
\left(\mu \mathrm{g} \mathrm{Cl} \mathrm{C}^{-1} \mathrm{~h}^{-1}\right)\end{array}$ & $\mathrm{SD}$ & $\mathrm{CV}$ & $\begin{array}{c}\mathrm{BCP}_{1} / \mathrm{BCP}_{2} \\
\text { ratio }\end{array}$ \\
\hline Rungsted harbour & 0.36 & 0.05 & 13.89 & 0.41 & 0.24 & 58.54 & 0.87 \\
\hline Frederikssund bridge & 0.49 & 0.30 & 61.22 & 0.41 & 0.25 & 60.98 & 1.21 \\
\hline Roskilde fjord & 1.33 & 0.44 & 33.08 & 1.10 & 0.36 & 32.73 & 1.21 \\
\hline Helsingør harbour & 0.23 & 0.08 & 34.78 & 0.31 & 0.11 & 35.48 & 0.74 \\
\hline Hundested & 0.28 & 0.03 & 10.71 & 0.42 & 0.05 & 11.90 & 0.67 \\
\hline Gilleleje & 0.35 & 0.06 & 17.14 & 0.30 & 0.02 & 6.67 & 1.17 \\
\hline Frederiksværk & 0.78 & 0.09 & 11.54 & 0.65 & 0.20 & 30.77 & 1.19 \\
\hline Kalundborg & 0.44 & 0.03 & 6.82 & 0.61 & 0.23 & 37.70 & 0.73 \\
\hline Average & & & 23.65 & & & 34.35 & $0.97 \pm 0.23$ \\
\hline
\end{tabular}

Table 3. Effect on the incorporation of thymidine 0,2 and $6 \mathrm{~h}$ after adding $0,10,50$ or $200 \mathrm{nM}$ leucine, for a freshwater and a marine location. Data are presented as the ratio between untreated (no leucine added) and treated samples. Standard deviation in parentheses; $\mathrm{n}=3$

\begin{tabular}{|c|c|c|c|}
\hline $\begin{array}{c}t \\
\text { (h after addition) }\end{array}$ & $10 \mathrm{nM}$ & $50 \mathrm{nM}$ & $200 \mathrm{nM}$ \\
\hline \multicolumn{4}{|c|}{ Rungsted Coast (marine location) } \\
\hline 0 & $1.07(0.10)$ & $1.03(0.15)$ & $0.93(0.36)$ \\
\hline 2 & $0.93(0.13)$ & $1.88(1.20)$ & $0.98(0.01)$ \\
\hline 6 & $0.92(0.16)$ & $0.73(0.03)$ & $0.91(0.21)$ \\
\hline \multicolumn{4}{|c|}{ Freshwater pond at the Water Quality Institute } \\
\hline 0 & $1.19(0.02)$ & $1.12(0.18)$ & $2.19(0.45)$ \\
\hline 2 & $1.29(0.08)$ & $1.22(0.27)$ & $1.29(0.08)$ \\
\hline 6 & $0.67(0.20)$ & $0.79(0.04)$ & $0.95 \quad(0.39)$ \\
\hline
\end{tabular}

0.05 for $200 \mathrm{nM}$ at $t=0$ ) in samples immediately ( $0 \mathrm{~h})$ after adding leucine (up to $200 \mathrm{nM}$ ) than in control samples without addition of leucine. Moreover, the same pattern was observed 2 and $6 \mathrm{~h}$ after additions of leucine.

\section{DISCUSSION}

One important aim of this study was to examine the magnitude of and day-to-day changes in the leucine isotope dilution and thus to define how often the isotope dilution need be determined.

There are 2 methodological approaches to correct for isotope dilution when a quantitative determination of bacterial production is carried out using leucine: (1) correcting the rates of incorporation for isotope dilution (Simon \& Azam 1989, Riemann \& Azam 1992), or (2) overwhelming the external pool of leucine by adding a concentration sufficiently high to maximally label the protein pool and at the same time to inhibit the de novo synthesis of leucine (Kirchman et al. 1985, Simon 1991).
Leucine and thymidine results were significantly correlated when all 3 periods were considered (Fig. 1) and when only the September data were compared (Fig. 5). Even though the majority of the data in Fig. 1 agreed well, the regression between thymidine and leucine covers a 5 -fold variation for single measurements. A similar variation was observed by Servais (1992), suggesting that a correction for isotope dilution is needed when a more precise determination of production is required. Moreover, the importance of correcting the leucine incorporation rates for isotope dilution was supported by the results from September (Fig. 5). A better correlation between leucine and thymidine incorporation rates was found after the leucine data were corrected for external isotope dilution. Before corrections for isotope dilution, average leucine production was 0.4 times thymidine-based production. After correcting the leucine data for isotope dilution, leucine-based production was 1.6 times higher than thymidine-based production (Fig. 5). Even though a slightly better correlation was found between results from thymidine and leucine, the relationship calculated in absolute figures was not improved. The reasons for this discrepancy are not clear; however, methodological and analytical problems with both leucine and thymidine (periods with unbalanced growth, linear incorporation kinetics, intracellular isotope dilution, non-specific incorporation of isotopes and the choice of conversion factor) are candidates to explain the observed variation (see below). It should be noted that the intercept on the $y$-axis (Fig. 5) indicated that leucine results were more than 2 times higher than thymidine, if the leucine results were corrected for isotope dilution using a general isotope dilution factor of 2.7 according to the results presented in Fig. 3. The 3 outliers in Fig. 3 all gave straight lines when incorporation rates were plotted versus concentration of leucine added (data not shown). The reason for such incorporation curves is not clear; we speculate whether multiphasic uptake, like the kinetic patterns 
reported for glucose uptake (Azam \& Hodson 1981), could occur.

To evaluate relationships between leucine and thymidine data, it is important to consider (1) the growth conditions of the bacterial assemblages, (2) the choice of methods to correct for non-specific incorporation and the subsequent choice of conversion factors to calculate the carbon production, and (3) isotope dilution by extracellular and intracellular sources.

Concerning the growth conditions, bacterial production in cultures determined from protein or DNA synthesis is the same only during balanced growth (Ingraham et al. 1983). In natural bacterial assemblages, balanced growth is sometimes found (Cuhel et al. 1983, Hanson \& Lowery 1983). On the other hand, Chin-Leo \& Kirchman (1990) demonstrated that during periods of unbalanced growth, leucine incorporation responds faster than thymidine incorporation. In a rapidly changing nutrient regime, such as a coastal environment, however, periods of unbalanced growth probably constitute a significant portion of time, suggesting periods with no couplings between protein and DNA synthesis. Nevertheless, many field observations generally produce a good correlation between thymidine and leucine incorporation (Kirchman \& Hoch 1988, Simon \& Azam 1989, Riemann et al. 1990, Servais 1992).

Concerning non-specific incorporation of both leucine and thymidine, ethanol rinsing of the filters has been proposed (Wicks \& Robarts 1988, Hollibaugh \& Wong 1992) to ensure a proper choice of conversion factor to calculate the protein and DNA synthesis, respectively, and to increase the precision of the measurement. Our results demonstrated that rates of leucine incorporation from ethanol-rinsed filters from 8 eutrophic environments were not significantly different from rates obtained from unrinsed filters. Hollibaugh \& Wong (1992) found using leucine that ethanol rinsing removed on average $22 \%$ of the cold TCA insoluble radioactivity and improved precision. Nevertheless, the percentage decrease in leucine incorporation rates after ethanol rinsing ranged from -4.7 to $67.6 \%$ suggesting a highly variable effect of ethanol. The improved precision of the measurements obtained from several other environmental samples (Hollibaugh \& Wong 1992) certainly call for an additional ethanol rinse. Whatever rinsing procedure is chosen, the subsequent choice of conversion factor to calculate bacterial production from rates of leucine incorporation should be carefully evaluated. The same conclusion can be drawn for thymidine. We rinsed our thymidine filters with $5 \%$ TCA only and used a conversion factor of $1.1 \times 10^{18}$ cells $\mathrm{mol}^{-1}$ thymidine incorporated (Riemann et al. 1987), determined from the same location in Roskilde Fjord. Published thymidine
Table 4. Isotope dilution and concentration of leucine applied in the literature

\begin{tabular}{|lll|}
\hline $\begin{array}{l}\text { Isotope } \\
\text { dilution }\end{array}$ & $\begin{array}{c}\text { Concentration } \\
\text { (nM) }\end{array}$ & \multicolumn{1}{c|}{ Source } \\
\hline $1-2.9$ & 10 & Simon \& Azam (1989) \\
$2.2-11.5$ & $0.5-10$ & Simon (1991) \\
4 & 10 & Chin-Leo \& Kirchman (1990) \\
$1-5$ & $10-11$ & Kirchman (1992) \\
$2.0-3.5$ & 30 & Simon \& Rosenstock (1992) \\
\hline
\end{tabular}

conversion factors range from $1 \times 10^{17}$ to $6 \times 10^{19}$ cells $\mathrm{mol}^{-1}$ incorporated (Riemann \& Bell 1990, Ducklow \& Carlson 1992, Robarts \& Zohary in press) with the majority of factors from marine environments ranging between 1 and $2 \times 10^{18} \mathrm{cells} \mathrm{mol}^{-1}$ thymidine incorporated. If a conversion factor of $1.8 \times 10^{18}$ instead of 1.1 $\times 10^{18}$ cells mol ${ }^{-1}$ thymidine incorporated is applied to our data, a 1 to 1 relationship is found between our leucine (corrected for isotope dilution; Fig. 5) and thymidine data.

Finally, isotope dilution influences the results of both leucine (Simon \& Azam 1989) and thymidine (Moriarty 1986). An isotope dilution of 2 to 3 has been found in many oligo- to mesotrophic waters, where leucine incorporation can be maximized using 10 to $30 \mathrm{nM}$ (Simon \& Azam 1989, Simon 1991). In our eutrophic coastal environments, however, external leucine concentrations are higher (Jørgensen 1982, 1987), and if no corrections are made for isotope dilution, the calculated rates can be off by a factor of 5 using $50 \mathrm{nM}$ (Table 1), or a factor of 2 using $100 \mathrm{nM}$. Published isotope dilution factors range from 1 to 11.8 (Table 4). Most of the factors in the range of 1 to 3.5 originate from oligo- to mesotrophic environments, and the high value of 11.8 was obtained using $0.5 \mathrm{nM}$ leucine (Simon 1991).

Another possibility to correct for isotope dilution is to add leucine in concentrations sufficiently high to maximally label the protein synthesis (Simon \& Azam 1989). In all 28 experiments, additions of 50 or $100 \mathrm{nM}$ leucine did not saturate the incorporation rate (Fig. 2), and the calculated $V_{\max }$ (Fig. 3) suggested that saturation occasionally would require additions of substantially higher concentrations. The magnitude of isotope dilution is directly related to the added leucine concentration: addition of a low leucine concentration produces a higher isotope dilution than addition of a higher leucine concentration (Fig. 5; Simon 1991 , Simon \& Rosenstock 1992). When isotope dilution was plotted against added leucine concentration (Fig. 5), an isotope dilution of 1 (indicating no isotope dilution) would require addition of $107 \mathrm{nM}$ leucine. The calculated SD of $123 \mathrm{nM}$ suggested, however, that additions 
of more than $230 \mathrm{nM}$ were required to maximally label the protein pool and avoid external isotope dilution. These rates are substantially higher than those previously recommended for many marine (Kirchman et al. 1985, Chin-Leo \& Kirchman 1988, Ducklow et al. 1992) and freshwater (Riemann \& Azam 1992, Servais 1992, Simon \& Rosenstock 1992) locations. Simon \& Azam (1989) cautioned that the degree of isotope dilution probably varied spatially and temporally and reported a 3-fold variation in isotope dilution when a $10 \mathrm{nM}$ leucine addition was used. The same patterns were found in Roskilde Fjord and day-to-day changes in isotope dilution varied markedly depending on the choice of leucine concentration (Fig. 4).

An important question is whether additions of high concentrations of leucine can induce changes in bacterial growth. Results from a freshwater pond and a coastal marine location (Table 3) suggest that additions of up to $200 \mathrm{nM}$ leucine did not change ${ }^{3} \mathrm{H}$-thymidine incorporation immediately after or up to $6 \mathrm{~h}$ after additions compared to the rates found in control samples without additions of leucine. Kirchman et al. (1985), Chin-Leo \& Kirchman (1988), and Simon \& Azam (1989) observed that additions of 100,25 or $10 \mathrm{nM}$ leucine, respectively, did not stimulate bacterial production during short incubations. An explanation for these observations might be that rates of protein synthesis are most likely limited by more than the supply of leucine (Kirchman et al. 1985), and that up to $91 \%$ of the leucine taken up is respired (Jørgensen 1992). The remaining $9 \%$ is probably not enough to stimulate the bacterial activity or DNA synthesis, except in oligotrophic oceanic waters (Kirchman et al. 1985). Kirchman et al. (1985) furthermore demonstrated that synthesis of other amino acids, which potentially could change the protein synthesis, did not occur in samples with added leucine up to $100 \mathrm{nM}$.

In conclusion, this study confirmed the significant correlation between leucine and thymidine incorporation rates. When leucine incorporation rates were corrected for isotope dilution, a slightly better correlation to thymidine incorporation was found. Significant dayto-day changes in isotope dilution occur in the shallow eutrophic environments examined, which makes it difficult to use a fixed factor to correct for isotope dilution. In order to correct for isotope dilution by the addition of high leucine concentrations to saturate the incorporation, it is necessary to add more than $200 \mathrm{nM}$ leucine.

Acknowledgements. We thank Morten Søndergaard and Farooq Azam for valuable comments on an earlier version of the manuscript, Winnie Martinsen and Kristian M. Christensen for technical assistance, and Kathleen G. Jensen for linguistic suggestions. This study was partly supported by the Danish Environmental Protection Agency (HAV90, contract no. 1.22) and by MAST II contract MAS2-CT92-0031-MEICE.

\section{LITERATURE CITED}

Azam, F., Hodson, R. E. (1981). Multiphasic kinetics for D-glucose uptake by assemblages of natural marine bacteria. Mar. Ecol. Prog. Ser. 6: 213-222

Billen, G., Servais, P., Fontigny, A. (1988). Growth and mortality in bacterial population dynamics of aquatic environments. Arch. Hydrobiol. Beih. Ergebn. Limnol. 31. $173-183$

Bjornsen, P. K. (1986). Bacterioplankton growth yield in continuous seawater cultures. Mar. Ecol. Prog. Ser. 30: 191-196

Bjørnsen, P. K., Kuparinen, J. (1991). Determination of bacterioplankton biomass, net production and growth efficiency in the Southern Ocean. Mar. Ecol. Prog. Ser. 71 : 185-194

Chin-Leo, G., Kirchman, D. L. (1988). Estimating bacterial production in marine waters from simultaneous incorporation of thymidine and leucine. Appl. environ. Microbiol. 54: $1934-1939$

Chin-Leo, G., Kirchman, D. L. (1990). Unbalanced growth in natural assemblages of marine bacterioplankton. Mar Ecol. Prog. Ser. 63: 1-8

Cole, J. J., Findlay, S., Pace, M. L. (1988). Bacterial production in fresh and saltwater ecosystems: a cross-system overview. Mar. Ecol. Prog. Ser. 43: 1-10

Cuhel, R. L., Jannasch, H. W., Taylor, C. D. (1983). Microbial growth and macromolecular synthesis in the northwestern Atlantic ocean. Limnol. Oceanogr. 28: 1-18

Ducklow, H. W., Carlson, C. A. (1992). Oceanic bacterial production. Adv. microb. Ecol. 12: 113-181

Ducklow, H. W., Kirchman, D. L., Quinby, H. L. (1992). Bacterioplankton cell growth and macromolecular synthesis in seawater cultures during the North Atlantic spring phytoplankton bloom, May, 1989. Microb. Ecol. 24: 125-144

Ducklow, H. W., Kirchman, D. L., Quinby, H. L., Carlson, C. A., Dam, H. G. (1993). Stocks and dynamics of bacterioplankton carbon during the spring bloom in the eastern North Atlantic Ocean. Deep Sea Res. 40: 245-263

Fuhrman, J. A., Azam, F. (1980). Bacterioplankton secondary production estimates for coastal waters of British Columbia, Antarctica and California. Appl. environ. Microbiol. 39: $1085-1095$

Hanson, R. B., Lowery, H. K. (1983). Nucleic acid synthesis in oceanic microplankton from the Drake Passage, Antarctica: evaluation of steady state growth. Mar. Biol. 73: $79-89$

Hobbie, J. E., Daley, R. J., Jasper, S. (1977). Use of Nuclepore filters for counting bacteria by fluorescence microscopy. Appl. environ. Microbiol. 33: 1225-1228

Hollibaugh, J. T., Wong, P. S. (1992). Ethanol extractable substrate pools and the incorporation and metabolism of thymidine, L-leucine and other low molecular weight substrates by bacterioplankton. Can. J. Microbiol. 38: $605-613$

Ingraham, J. L., Maaløe, O., Neidhardt, F. C. (1983). Growth of the bacterial cell. Sinauer Associates, Sunderland, MA

Jørgensen, N. O. G. (1982). Heterotrophic assimilation and occurrence of dissolved free amino acids in a shallow estuary. Mar. Ecol. Prog. Ser. 8: 145-159

Jorgensen, N. O. G. (1987). Free amino acids in lakes: concentrations and assimilation rates in relation to phytoplankton and bacterial production. Limnol. Oceanogr. 32 : $97-111$

Jørgensen, N. O. G. (1992). Incorporation of $\left[{ }^{3} \mathrm{H}\right]$ leucine and $\left[{ }^{3} \mathrm{H}\right]$ valine into protein of freshwater bacteria: uptake kinetics and intracellular isotope dilution. Appl. environ. Microbiol. 58: 3638-3646 
Kirchman, D. L. (1992). Incorporation of thymidine and leucine in the subarctic Pacific: application to estimating bacterial production. Mar. Ecol. Prog. Ser. 82: 301-309

Kirchman, D. L., Hoch, M. P. (1988). Bacterial production in the Delaware Bay estuary estimated from thymidine and leucine incorporation rates. Mar. Ecol. Prog. Ser. 45: $169-178$

Kirchman, D. L., K'nees, E., Hodson, R. E. (1985). Leucine incorporation and its potential as a measure of protein synthesis by bacteria in natural aquatic ecosystems. Appl. environ. Microbiol. 49: 599-607

Leatherbarrow, R. J. (1987). A non-linear regression data analysis program for the IBM PC. Elsevier-Biosoft, Cambridge

Lee, S., Fuhrman, J. A. (1987). Relationships between biovolume and biomass of naturally derived marine bacterioplankton. Appl. environ. Microbiol. 53: 1298-1303

Moriarty, D. J. W. (1986). Measurements of bacterial growth rates in aquatic systems using rates of nucleic acid synthesis. Adv. microb. Ecol 9: 245-292

Riemann, B., Azam, F. (1992). Measurements of bacterial protein synthesis in eutrophic aquatic environments by means of leucine incorporation. Mar. microb. Food Webs 6: $91-105$

Riemann, B., Bell, R. T. (1990). Advances in estimating bacterial biomass and growth in aquatic ecosystems. Arch. Hydrobiol. 118: 385-402

Riemann, B., Bell, R. T., Jørgensen, N. O. G. (1990). Incorporation of thymidine, adenine and leucine into natural bac-

This article was submitted to the editor terial assemblages. Mar. Ecol. Prog. Ser, 65: 87-94

Riemann, B., Bjørnsen, P. K., Newell, S., Fallon, R. (1987). Calculation of cell production of coastal marine bacteria based on measured incorporation of $\left[{ }^{3} \mathrm{H}\right]$ thymidine. Limnol. Oceanogr. 32: 471-476

Robarts, R. D., Zohary, T (in press). Fact or fiction - bacterial growth rates and production as determined by $\left[{ }^{3} \mathrm{H}-\right.$ methyl] thymidine. Adv. microb. Ecol.

Servais, P. (1992). Bacterial production measured by ${ }^{3} \mathrm{H}$ thymidine and ${ }^{3} \mathrm{H}$-leucine incorporation in various aquatic ecosystems. Arch. Hydrobiol. Beih. 37: 73-81

Simon, M. (1991). Isotope dilution of intracellular amino acids as a tracer of carbon and nitrogen sources of marine planktonic bacteria. Mar. Ecol. Prog. Ser. 51. 201-213

Simon, M., Azam, F. (1989). Protein content and protein synthesis rates of planktonic marine bacteria. Mar. Ecol. Prog. Ser. 51: 201-213

Simon, M., Rosenstock, B. (1992). Carbon and nitrogen sources of planktonic bacteria in Lake Constance studied by the composition and isotope dilution of intracelllular amino acids. Limnol. Oceanogr. 37: 1496-1511

Wicks, R. L., Robarts, R. D. (1988). Ethanol extraction requirements for purification of protein labeled with $\left[{ }^{3} \mathrm{H}\right]$ leucine in aquatic bacterial production studies. Appl. environ Microb. 54: $3191-3193$

Winding, A. (1992). $\left[{ }^{3} \mathrm{H}\right]$ Thymidine incorporation to estimate growth rates of anaerobic bacterial strains. Appl. environ. Microb. 8: 2660-2662

Manuscript first received: May 5, 1993

Revised version accepted: August 30, 1993 